\title{
MOLECULAR ANALYSIS OF FRAGILE X SYNDROME IN ANTALYA PROVINCE
}

\author{
T. BILGEN, I. KESER, E. MIHCI*, S. HASPOLAT**, S. TACOY*, G. LULECI
}

\section{ABSTRACT}

BACKGROUND: Detection of the $(C G G)_{n}$ repeats in the FMR1 gene that cause the fragile $X$ syndrome (FXS), has become a milestone for phenotype-genotype correlation in FXS. AIMS: To screen the FMR1 gene CGG repeats in index cases with FXS and their family members in the Antalya Province. SETTING AND DESIGN: This study was prospectively conducted between January 2000 and March 2005 in Department of Medical Biology and Genetics, Faculty of Medicine, Akdeniz University, Antalya. MATERIALS AND METHODS: A series of 132 cases from three hospitals in Antalya Province were studied. All cases were molecularly screened using non-radioactive Expand Long PCR method that was confirmed by Southern blotting. RESULTS: Seventeen out of 132 cases were found to have a full mutation, including three that were mosaic for premutations/full mutations. Of the 132 cases, eight were found to have the premutation size of the CGG repeats. The remaining 107 cases were identified as normal. CONCLUSIONS: Due to premature ovarian failure and Fragile $X$ premutation Tremor/Ataxia Syndrome related with the premutation, the detection of the premutation will provide valuable information both for clinical follow-up and genetic counseling. In conclusion, our data suggest that expansion of CGG repeats in the FMR1 gene can be analyzed by Expand Long PCR, an efficient and non-radioactive method that can be used to monitor the expansion of premutation to full mutation, which would eventually lead to reduce the FXS prevalence.

KEY WORDS: Antalya, CGG repeats, expand long PCR, fragile $X$ syndrome, FMR 1 gene

The fragile $X$ syndrome (FXS) is the most common inherited form of mental retardation. The molecular basis of the syndrome is usually an expansion of a repetitive CGG triplet sequence located in the 5'-untranslated region (5'-UTR) of the FMR1 gene. ${ }^{[1]}$ Rarely, FXS results from other molecular alterations (such as point mutations or deletions) within the FMR1 gene. ${ }^{[2]}$ The normal number of (CGG)

Departments of Medical Genetics, *Pediatric Clinical Genetics and **Pediatric Neurology, School of Medicine, Akdeniz University, Antalya, Turkey repeats is polymorphic and varies from 6 to 50. ${ }^{[3]}$ When the expanded repeat numbers range from 50 to 200 , the allele becomes unstable in the intergenerational transmissions and is termed as premutation. ${ }^{[4]}$ The expansion of the number of repeats above a threshold of approximately 200 repeats, results in hypermetylation of the FMR1 promotor region and a lack of gene expression. This allele is

Correspondence:

Dr. Ibrahim Keser, Department of Medical Genetics, School of Medicine, Akdeniz University, TR-07070 Antalya, Turkey. E-mail: keser@akdeniz.edu.tr 
termed as full mutation. Alleles with $>200$ triplets are highly unstable during somatic development and inheritance. Alleles that are called 'Grey zone' (approximately 50-60 triplets) are stable in somatic development, yet their stability in transmission is unpredictable. ${ }^{[5]}$ Mosaicism, methylation and size mosaicisms, is also frequent in the FXS and closely associated with clinical variability. Although the frequency of FXS has been estimated to be approximately 1 in 4000 males and 1 in 6000 females, ${ }^{[6,7]}$ the frequency of premutation in the general population is $\sim 1$ in 259 females and 1 in 813 males. ${ }^{[8,9]}$ The premutation in the FMR1 gene has been reported to be associated with premature ovarian failure. ${ }^{[10]}$ On the other hand, recently, Jacquemont et al ${ }^{[11]}$ reported fragile $X$ premutation tremor/ataxia syndrome in a series of 26 patients, all $>50$ years of age, who were carriers of the fragile $X$ premutation, and affected by a multisystem, progressive neurological disorder. Due to increasing clinical importance and high prevalence, the identification of the premutation carriers, which can be detected only by direct molecular analysis is very important. ${ }^{[12]}$ Here, we aimed to detect the mutations by using an efficient and reliable PCR protocol which enables the amplification of normal, premutated and full mutated alleles in index cases and in members of the families with FXS, and to give effective genetic counseling in the Antalya Province.

\section{MATERIALS AND METHODS}

We prospectively analyzed DNA samples isolated from the peripheral blood of 95 males and two females who had been clinically diagnosed as having FXS according to Hagerman's Checklist (see http:// www.fragilex.org/html/checklist.htm) and 42 members in the seven families of those probands we detected to have FXS by molecular analysis (132 cases in total) between January 2000 and March 2005. Final examination and scoring of all cases was performed by two different professional physicians from the Departments of Pediatric Neurology and Clinical Genetics, School of Medicine, Akdeniz University. Index cases with a score of 13 or higher for the Hagerman's Checklist were included in this study. Signed written consents were taken from all subjects or their parents. This study was also approved by the ethics committee of the Faculty of Medicine, Akdeniz University. The amplification primers were Fra X-Forward: 5'-ACC TCT gCA gAA ATg ggC gTT CTg gCC CTC-3' and Fra X-Reverse: 5'-CTA gCg CCg ggA gCC CgC CCC CgA gAg gT-3'. Amplification of the CGG repeat region of normal, premutated and full mutated alleles in the FMR1 gene was carried out by PCR reaction with a total volume of $25 \mathrm{ml}$, containing $200 \mathrm{ng}$ of genomic DNA, $300 \mathrm{nM}$ of each primer, $5 \%$ of DMSO, $5 \%$ glycerol, Expand Long PCR buffer 1,350 nM each of dATP, dCTP, dTTP, 7-deaza dGTP, and $1 \mathrm{U}$ Expand Long PCR Enzyme Mix. Denaturation was performed at $95^{\circ} \mathrm{C}$ for $3 \mathrm{~min}$. The samples were then subjected to 10 cycles of amplification $\left(95^{\circ} \mathrm{C}\right.$ for $30 \mathrm{~s}, 54^{\circ} \mathrm{C}$ for $30 \mathrm{~s}$, $68^{\circ} \mathrm{C}$ for $8 \mathrm{~min}$ ) in a thermocycler (Techne Genius). The reaction was stopped on ice, following the last denaturation for further addition of an enzyme $(1 \mathrm{U})$, and continued for 30 more cycles $\left(95^{\circ} \mathrm{C}\right.$ for $30 \mathrm{~s}, 52^{\circ} \mathrm{C}$ for $30 \mathrm{~s}$, $68^{\circ} \mathrm{C}$ for $8 \mathrm{~min}$ ). The elongation time was extended for $5 \mathrm{sec}$. after each cycle in the last 30 cycles. The reaction was finalized by keeping the reaction at $68^{\circ} \mathrm{C}$ for $18 \mathrm{~min}$, then at $4^{\circ} \mathrm{C}$. The PCR product was run on $1.2 \%$ agarose gel with DIG labeled molecular weight marker (MW, VII; Boehringer Mannheim) and transferred to a positively charged nylon membrane (Boehringer Mannheim) following denaturation and neutralization procedures. DNA was cross-linked to the membrane by UV light. Blot was prehybridized for $1 \mathrm{~h}$ then hybridized with DIG labeled $5^{\prime}$-(CGG) ${ }_{5}-3^{\prime}$ probe in DIG Hybridization Buffer at $60^{\circ} \mathrm{C}$ shaking in a hybridization oven for $16 \mathrm{~h}$. After washing off the membrane, the bands were detected according to the procedures described in the DIG-Luminescent Detection Kit (Boehringer Mannheim). After the incubation of CSPD at $37^{\circ} \mathrm{C}$ for $15 \mathrm{~min}$, the membrane was exposed to Hyper ECL film (Amersham) for 1015 min. ${ }^{[13,14]}$ Normal, premutation and full mutation DNA samples were ran in each study as a control and premutations and full mutations were confirmed by Southern blotting during the initial studies. ${ }^{[15]}$

\section{RESULTS}

Ten of the 97 index cases were found to have full mutation by Expand Long PCR-based method. Two out of ten had both a premutation and full mutation band. A smear pattern was detected in the other eight patients. The remaining 87 cases were found to have normal sizes of the CGG repeats. Excluding seven index cases, 15 of 42 members in seven families were found to have an increase of the CGG repeats. Seven and eight of these were carriers of full mutations and premutations, respectively. One out of seven full mutation carriers had both premutation and full mutation sized bands. The remaining 20 members of the families had normal size of the CGG repeats.
The results of the FMR1 (CGG) mutation analysis in seven families are shown in Table 1. Figures $1 \mathrm{~A}$ and $1 \mathrm{~B}$ show the step-increasing transmission of the CGG repeats in one of the families. The premutation was transmitted with a little expansion in the premutation range from female (grandmother) (I-2) to female (mother) (II-2), then expanded to full mutation in the child (grandson) (III-2) in Family 4. Two of the mosaic patterns were transmitted from a mother with full mutation in Families 1 and 3 , respectively. The remaining one, from Family 2 , was observed to be transmitted by a mother with premutation (Table 1)

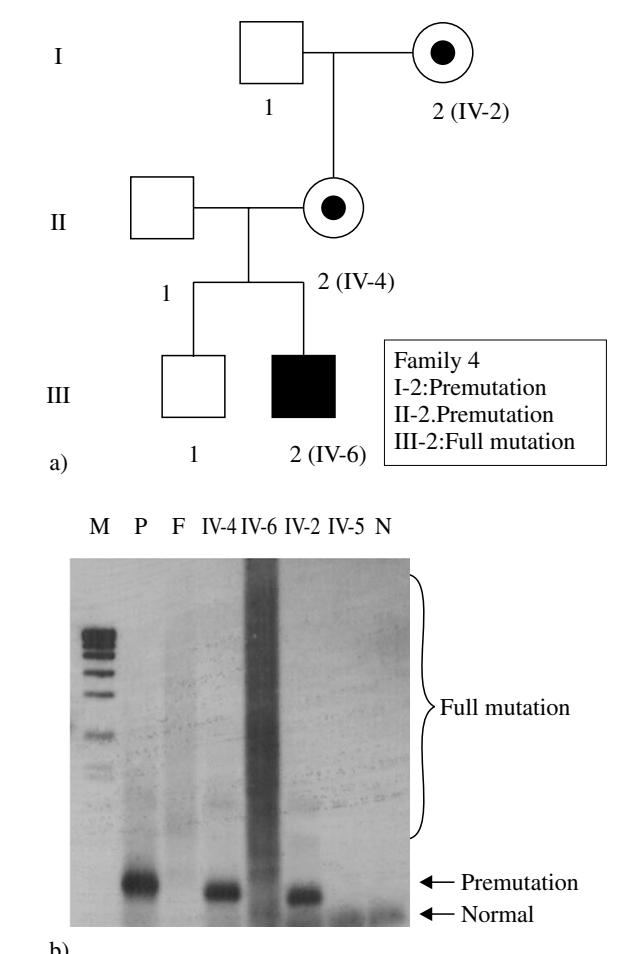

Figure 1: A family with FXS showing the inheritance of the premutation to full mutation in the generations. (A) Pedigree, (B) index case (4-6) with full mutation, his mother (4-4) with premutation, his grandmother (4-2) with premutation, and his brother (4-5) normal in Family 4. M: DIG labeled marker; N: normal control; P: premutation control; $F$ : full mutation control 
Table 1:The results of FMR1 gene mutation analysis in $\mathbf{4 2}$ members in seven families with FRXS

\begin{tabular}{|c|c|c|}
\hline Family/case & $\begin{array}{l}\text { FMR1 mutation } \\
\text { status }\end{array}$ & $\begin{array}{l}\text { Approximate } \\
(C G G)_{n}\end{array}$ \\
\hline \multicolumn{3}{|l|}{ Family 1} \\
\hline Grandfather & Normal & 40 \\
\hline Grandmother & Premutation & 85 \\
\hline Father & Normal & 35 \\
\hline Mother & Full mutation & 40 and $200<$ \\
\hline Aunt & Full mutation & 40 and $200<$ \\
\hline Brother & $\begin{array}{l}\text { Premutation/ } \\
\text { full mutation }\end{array}$ & 120 and $200<$ \\
\hline Sister & Normal & 35 and 40 \\
\hline $\begin{array}{l}\text { Index case }^{\dagger} \\
\text { Family } 2\end{array}$ & Full mutation & $200<$ \\
\hline Grandfather & Normal & 30 \\
\hline Grandmother & Premutation & 30 and 80 \\
\hline Father & Normal & \\
\hline Mother & Premutation & 30 and 100 \\
\hline Sister & Normal & 25 and 30 \\
\hline Sister & Normal & 25 and 30 \\
\hline Index case ${ }^{\dagger}$ & $\begin{array}{l}\text { Premutation/ } \\
\text { full mutation }\end{array}$ & 110 and $200<$ \\
\hline \multicolumn{3}{|l|}{ Family 3} \\
\hline Father & Normal & 30 \\
\hline Mother & Full mutation & 40 and $200<$ \\
\hline Index case ${ }^{\dagger}$ & $\begin{array}{l}\text { Premutation/ } \\
\text { full mutation }\end{array}$ & 90 and $200<$ \\
\hline $\begin{array}{l}\text { Brother } \\
\text { Family } 4\end{array}$ & Full mutation & $200<$ \\
\hline Grandfather & Normal & 35 \\
\hline Grandmother & Premutation & 35 and 70 \\
\hline Father & Normal & 25 \\
\hline Mother & Premutation & 35 and 75 \\
\hline Brother & Normal & \\
\hline Index case ${ }^{\dagger}$ & Full mutation & $200<$ \\
\hline $\begin{array}{l}\text { Family } 5 \\
\text { Father }\end{array}$ & Normal & Family 5 \\
\hline Mother & Premutation & 30 and 80 \\
\hline Aunt & Premutation & 30 and 80 \\
\hline Aunt's husband & Normal & 35 \\
\hline Sister & Normal & 30 and 30 \\
\hline Index case ${ }^{\dagger}$ & Full mutation & $200<$ \\
\hline Cousin (female) & Full mutation & 30 and $200<$ \\
\hline Cousin (male) & Normal & 30 \\
\hline \multicolumn{3}{|l|}{ Family 6} \\
\hline Father & Normal & \\
\hline Mother & Full mutation & 35 and $200<$ \\
\hline Index case ${ }^{\dagger}$ & Full mutation & $200<$ \\
\hline \multicolumn{3}{|l|}{ Family 7} \\
\hline Father & Normal & 25 \\
\hline Mother & Premutation & 25 and 90 \\
\hline Aunt & Normal & 25 and 40 \\
\hline Aunt & Normal & 25 and 40 \\
\hline Aunt & Normal & 25 and 40 \\
\hline Index case ${ }^{\dagger}$ & Full mutation & $200<$ \\
\hline
\end{tabular}

${ }^{\dagger}$ All index cases are males.

\section{DISCUSSION}

In our laboratory, the fragile $X$ mutations had been analyzed using both cytogenetic and genomic Southern blotting (with StB12.3 probe and double digestion) until 2001. ${ }^{[15]}$ We also started to analyze simultaneously the fragile $X$ mutations using the Expand Long PCR protocol in probands and their families. In the present study, using this protocol, we found ful mutation in 10 of the 97 index cases who have a score of 13 or higher according to Hagerman's Checklist. Seven full mutations and eight premutation carriers were also found among 42 members of their families. The DNA analysis of families with apparently isolated cases of FXS indicates that even distant relatives are at risk to be carriers. For this reason, it is imperative that members of these families be offered FMR1 DNA studies. Our results suggest that this technique is useful to detect the intergenerational instability of CGG repeats in the FMR1 gene in index cases with FXS and in their families. However, in general, the only limitation of this technique is the smear appearance of full mutations (Figure 1B). Although full mutations were detected mostly as a smear, the three patients who had both full mutation and premutationsized fragments were also identified. These band patterns may or may not reflect the true heterogeneity of genomic DNA isolated from peripheral blood. Also, these band patterns observed in peripheral blood may or may not reflect the true heterogeneity of brain and other tissues. Two of the mosaic patients were index cases with mental retardation (Family 2-7 and Family 3-3 in Table 1). The other one was a member of Family 1 with mild mental retardation (Family 1-6 in Table 1). This clinical difference may be due to the ratio of the premutation and full mutation in the brain neurons. Also, these findings show that all family members with or without clinical features should be screened in the families with FXS.

An issue for mothers with premutation alleles is the possibility of transmitting a full mutation to her offspring, as well as premature ovarian failure, ${ }^{[16]}$ which we could not study in the women with premutation. In 2001, a new condition was reported in some adult males with premutation, it was called Fragile X Tremor ataxia syndrome (FXTAS).[11,17,18] These findings raised additional issues that should be considered by genetic counselors. In our study, no males with premutation were found, but there were three mosaic males. Due to no welldescribed clinical features and the high prevalence of premutation carriers, the premutation carriers must be diagnosed by an efficient molecular technique such as the PCRbased method that can identify accurately the CGG repeat size, and that we used in the present study. Two male fetuses were prenatally diagnosed with this method, one had a normal allele and the other carried a full mutation. These results were confirmed by Southern blot using Eagl/EcoRI double digestions. We started the screening of the general population for the prevention of the birth of a child with FXS or beta-thalassemia in Antalya. The index cases that were found to be normal for the CGG repeats will be screened to detect other molecular alterations (such as point mutations and deletions) in the FMR1 gene. We believe that the recording and following of families with FXS will provide prenatal diagnosis and the usage of a possible treatment opportunity in the future. As a result, our data show that all the members with/ without clinical findings of FXS in the families with FXS should be screened by the PCR based method to follow the transmission of the CGG repeats and to give correct genetic counseling to families.

\section{ACKNOWLEDGMENT}

This study was supported by the Research Foundation of the Akdeniz University.

\section{REFERENCES}

1. Brown WT, Nolin $S$, Houck $G$ Jr, Ding $X$ Glicksman A, Li SY, et al. Prenatal diagnosis and carrier screening for fragile X by PCR. Am J Med Genet 1996:64:191-5.

2. Castellvi-Bel $S$, Sanchez A, Badenas $C$, Mallolas J, Barcelo A, Jimenez D, et al. Single-strand comformation polymorphism analysis in the FMR1 gene. Am J Med Genet 1999;84:262-5

3. Kallinen $J$, Heinonen $S$, Mannermaa $A$, Ryynanen M. Prenatal diagnosis of fragile $X$ syndrome and the risk of expansion of a premutation. Clin Genet 2000;58:111-5.

4. Willemsen R, Oostra BA. FMRP detection assay for the diagnosis of the fragile $X$ syndrome. Am $J$ Med Genet 2000;97:183-8.

5. Dobkin C, Ding $X$, Li S, Houck G Jr, Nolin SL, Glicksman A, et al. Accelerated prenatal diagnosis of fragile $\mathrm{X}$ syndrome by polymerase chain reaction restriction fragment detection. Am J Med Genet 1999;83:338-41.

6. de Vries BB, van den Ouweland AM Mohkamsing S, Duivenvoorden HJ, Mol E Gelsema K, et al. Screening and diagnosis for the fragile $X$ syndrome among the mentally retarded: An epidemiological and psychological survey. Collaborative Fragile X Study Group. Am J Hum Genet 1997;61:660-7.

7. Turner G, Webb T, Wake S, Robinson $\mathrm{H}$, et al. 
Prevalence of fragile $\mathrm{X}$ syndrome. Am J Med Genet 1996;64:196-7.

8. Rousseau F, Rouillard P, Morel ML, Khandjian EW, Morgan K. Prevalence of carriers of premutation-size alleles of the FMRI gene - and implications for the population genetics of the fragile $X$ syndrome. Am J Hum Genet 1995;57:1006-18.

9. Dombrowski C, Levesque S, Morel ML, Rouillard P, Morgan K, Rousseau F. Premutation and intermediate-size FMR1 alleles in 10572 males from the general population: loss of an AGG interruption is a late event in the generation of fragile $X$ syndrome alleles. Hum Mol Genet 2002;11:371-8.

10. Allingham-Hawkins DJ, Babul-Hirji R, Chitayat D, Holden JJ, Yang KT, Lee C, et al. Fragile $X$ premutation is a significant risk factor for premature ovarian failure: The International Collaborative POF in Fragile X study preliminary data. Am J Med Genet 1999;83:322-5.

11. Jacquemont $S$, Hagerman RJ, Leehey $M$, Grigsby J, Zhang L, Brunberg JA, et al. Fragile $X$ premutation tremor/ataxia syndrome: Molecular, clinical, and neuroimaging correlates. Am J Hum Genet 2003;72:869-78.
12. Toledano-Alhadef $\mathrm{H}$, Basel-Vanagaite $\mathrm{L}$, Magal N, Davidov B, Ehrlich S, Drasinover V, et al. Fragile-X carrier screening and the prevalence of premutation and full-mutation carriers in Israel. Am J Hum Genet 2001;69:351-60.

13. Hecimovic S, Barisic I, Muller A, Petkovic I, Baric I, Ligutic I, et al. Expand Long PCR for fragile $X$ mutation detection. Clin Genet 1997;52:147-54.

14. Uyguner ZO, Wollnik B, Kayserili $H$, Tükel $T$, Basaran S, Apak MY. Establishment of a nonradioactive molecular diagnosis of fragile $X$ syndrome. Turk J Med Sci 2000;30:253-60.

15. Keser I, Luleci G, Alkan M. The results of molecular and cytogenetic analysis in 6 families with fragile- $X$ syndrome in Turkey. Marmara Med J 2000;13:7-10.

16. Sherman SL. Premature ovarian failure in the fragile $X$ syndrome. Am J Med Genet 2000;97:189-94.

17. Tassone F, Hagerman RJ, Taylor AK, Gane LW, Godfrey TE, Hagerman PJ. Elevated levels of FMR1 mRNA in carrier males: A new mechanism of involvement in the fragile- $X$ syndrome. Am J Hum Genet 2000;66:6-15.

18. Hagerman RJ, Hagerman PJ. The fragile $X$ premutation: Into the phenotypic fold. Curr Opin Genet Dev 2002;12:278-83. 